\title{
COMMENTS
}

\section{Defining “Otherwise Qualified Applicants": Applying an Antitrust Relevant-Market Analysis to Disparate Impact Cases}

\author{
Scott Baker $\dagger$
}

A plaintiff making a Title VII disparate impact claim must show that an employer's hiring practice, test, or requirement tends to exclude members of a protected class. ${ }^{1}$ In other words, the plaintiff must show that the practice in question causes the employer's workforce to have a smaller percentage of minorities than the qualified applicant pool. ${ }^{2}$ Because the result of this comparison rests on the question of who is a qualified applicant, both plaintiffs and defendants seek to shape the qualified applicant pool determination in their favor.

The disparate impact plaintiff would like to show that the qualified applicant pool contains many persons in the protected class. Assuming the employer's workforce does not contain many such persons, such a showing allows the plaintiff to establish the prima facie case of discrimination easily under a disparate impact theory. In contrast, the defendant would like to show that the minority composition of the qualified applicant pool perfectly mirrors the minority composition of

$\dagger$ B.A. Miami University 1994; J.D. Candidate 2000, The University of Chicago; Ph.D. Candidate (Economics) 2001, University of North Carolina at Chapel Hill.

1 Title VII makes it unlawful for an employer to "fail or refuse to hire or to discharge any individual, or otherwise to discriminate against any individual with respect to his compensation, terms, conditions, or privileges of employment, because of such individual's race, color, religion, sex, or national origin." Civil Rights Act of 1964, Pub L No 88-352, 78 Stat 255, codified at 42 USC $\$ 2000 \mathrm{e}-2(\mathrm{a})(1)(1994)$.

2 See Wards Cove Packing Co v Atonio, 490 US 642, 650-51 (1989) (stating that a comparison "between the racial composition of the qualified persons in the labor market and the persons holding at-issue jobs ... generally forms the proper basis for the initial inquiry in a disparate-impact case"). 
the employer's workforce. Thus, in disparate impact cases an important threshold question exists:.who is a qualified applicant?

The Supreme Court has provided little guidance for lower courts to use when deciding this issue. As a result, lower courts have resolved the issue in inconsistent ways that often do not take into account the basic economic theory of labor markets.

This Comment argues that the same economic and legal principles that courts use to define the relevant commodity market in monopolization cases ${ }^{3}$ should be used to define the relevant labor market (i.e., the qualified applicant pool) in Title VII disparate impact cases. Applying relevant-market principles from antitrust law in disparate impact cases will achieve two goals: (1) it will increase the predictability of applicant pool determinations, and (2) it will force litigants to couch, and courts to decide, labor market issues within a coherent economic and legal framework. Therefore, courts should look to well developed antitrust caselaw for guidance in determining the scope and the shape of the qualified applicant pool. ${ }^{5}$

Part I of this Comment sets out the legal doctrine underlying the disparate impact theory of discrimination. It outlines some of the methods that courts currently use to determine the scope of the qualified applicant pool and demonstrates that these methods often do not reflect the basic economic principles that underlie labor market behavior. Part II illustrates that labor markets are no different than commodity markets from an economic theory standpoint. Part III outlines the legal tests used to define the relevant commodity market in monopolization cases, ${ }^{6}$ and shows how antitrust law's relevant-

3 . The Sherman Act makes monopolization unlawful. The Act states that "[e]very person who shall monopolize, or attempt to monopolize, or combine or conspire with any other person or persons, to monopolize any part of the trade or commerce among the several States ... shall be deemed guilty of a felony." Sherman Act, 26 Stat 209 (1890), as amended by Pub L No 93-528, 88 Stat 1708 (1974), codified at 15 USC $\$ 2$ (1994).

4 Application of antitrust principles will also provide a response to the claim that the qualified applicant pool determination is simply an ad hoc determination on the part of the district court. See Marcel C. Garaud, Comment, Legal Standards and Statistical Proof in Title VII Litigation: In Search of a Coherent Disparate Impact Model, 139 U Pa L Rev 455, 474 (1990) (stating that "[ $[\mathrm{t}] \mathrm{he}$ process of determining the qualified applicant pool will result in a set of figures that is nothing more than a 'guesstimate' of the number of qualified applicants").

- 5 This is not the first Comment to advocate applying antitrust principles to Title VII cases. See Rachel L. Cantor, Comment, Consumer Preferences for Sex and Title VII: Employing Market Definition Analysis for Evaluating BFOQ Defenses, 1999 U Chi Legal F 493 (applying an antitrust analysis to determine when "sex" is a business product and therefore a legitimate defense to a claim of sex discrimination).

6 Note that defining the relevant market is also important in evaluating mergers under Section 7 of the Clayton Act. 38 Stat 731 (1914), codified at 15 USC $\S 18$ (1994). The same legal principles underscore the definition of the relevant market for monopolization purposes as for merger evaluation purposes. See Julian $O$. von Kalinowski, Peter Sullivan, and Maureen McGuirl, Antitrust Laws and Trade Regulation § 24.01[4] (Matthew Bender 2d ed 1999) ("In defining the market in a Section 7 case it is permissible to consult market definitions in Section 2 
market principles provide a sensible legal test for determining the scope and shape of the relevant qualified applicant pool in Title VII cases. Part IV offers an example of how district courts could easily apply the test proposed in Part III.

\section{TITLE VII AND THE DisPaRATE IMPACT THEORY OF DISCRIMINATION}

Disparate impact as a form of discrimination is based on the premise that an employer's hiring requirements, though facially neutral, can have discriminatory effects on a protected class. The Supreme Court recognized disparate impact as a viable discrimination theory under Title VII soon after its passage, ${ }^{8}$ and has since issued a number of decisions tangentially related to the determination of the

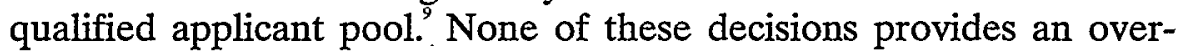
arching principle for deciding the scope and shape of the qualified applicant pool. In fact, from a district court's perspective, the only thing the Supreme Court has said in this regard is that labor market participants qualified for the job at issue (and only those participants) should be included in the qualified applicant pool. ${ }^{10}$ Such a tautology provides little practical assistance to lower court judges. As a result, lower courts have applied an array of methods to determine what constitutes the qualified applicant pool. Unfortunately, these methods are often inconsistent with each other and with the basic economic theory of labor markets.

cases and vice versa.").

7 See Griggs v Duke Power Co, 401 US 424,430 (1971) (stating that under Title VII "practices, procedures, or tests neutral on their face, and even neutral in terms of intent, cannot be maintained" if discriminatory in operation).

8 Id.

9 See, for example, Wards Cove Packing Co v Atonio, 490 US 642 (1989) (holding that a comparison between minority workers in cannery positions and minority workers in noncannery positions was not relevant in determining if a hiring practice had a disparate impact); Hazelwood School District v United States, 433 US 299 (1977) (holding that a statistical comparison between the minority composition of the student body and the minority composition of the teachers in a school was irrelevant to determining the existence of discrimination); International Brotherhood of Teamsters $v$ United States, 431 US 324 (1977) (finding that a statistical comparison between line truck drivers and the general population was relevant to determining the existence of discrimination).

10 See Hazelwood, 433 US at 308 (stating that the "proper comparison [is] between the racial composition of [the job at issue] and the racial composition of the qualified ... population in the relevant labor market"). 


\section{A. From Griggs to Wards Cove: The Supreme Court Precedent Governing Disparate Impact Cases}

The Supreme Court first recognized disparate impact as a theory of discrimination in Griggs $v$ Duke Power Co." In Griggs, a group of black plaintiffs challenged Duke Power's hiring requirements that workers have a high school degree and pass two general intelligence tests. ${ }^{12}$ The plaintiffs claimed that the requirements were unrelated to job performance and, because blacks were less likely to satisfy these requirements, that Duke Power had effectively excluded blacks from the workplace. ${ }^{13}$

The district court dismissed the plaintiffs' claim, finding that Duke Power did not have any discriminatory intent when it adopted its hiring requirements. ${ }^{14}$ The appellate court affirmed, holding that discriminatory intent was an essential element of a Title VII claim. ${ }^{\text {s }}$ The Supreme Court then reversed, concluding that "[Title VII] proscribes not only overt discrimination but also practices [or hiring requirements] that are fair in form, but discriminatory in operation." ${ }^{16}$ The Court ruled that Title VII prohibits employment practices that have a disparate impact on a protected class. ${ }^{17}$

The Griggs Court also created an exception to this general rule. If a hiring practice, test, or requirement-fair in form, but discriminatory in operation-is related to job performance, then it is not prohibited under Title VII.

The Court next visited the disparate impact cause of action in $\mathrm{Al}$ bemarle Paper Co v Moody. ${ }^{19}$ In Moody, the Court set forth a threepart burden-shifting test for evaluating disparate impact claims. First, the plaintiff must make out a prima facie case of disparate impact by showing "that the tests in question select applicants for hire or promotion in a racial pattern significantly different from that of the pool of applicants. ${ }^{, 20}$ Next, if the plaintiff makes this showing, then the burden

11401 US 424, 431 (1971).

12 Id at 426 .

13 Id.

14 Id at 428 .

15 Id (describing the court of appeals holding that because "there was no showing of a discriminatory purpose in the adoption of the diploma and test requirements" there was no Title VII violation).

16 Id at 431 (holding that Title VII does not require discriminatory intent, only discriminatory consequences and a lack of business necessity, to constitute a violation).

17 Id (making an analogy between a test with a disparate impact and the "fabled offer of milk to the stork and the fox").

18 In particular, the Court noted: "The touchstone is business necessity. If an employment practice which operates to exclude [protected classes] cannot be shown to be related to job performance, the practice is prohibited." Id.

19422 US 405 (1975).

20 Id at 425. The Court in Albemarle did not define what constituted the appropriate quali- 
shifts to the employer to show that the employment requirements are job related. ${ }^{21}$ Finally, if the defendant meets this burden, then the burden shifts back to the plaintiff to show that other tests-that would not have a disparate impact-would also serve the employer's legitimate interest in hiring efficient and trustworthy employees. ${ }^{2}$ Although the plaintiff's and defendant's burden of proof requirements were clear after Albemarle, what constituted the "pool of applicants" - the qualified applicant pool-necessary for assessing a plaintiff's prima facie case remained largely undefined.

International Brotherhood of Teamsters $v$ United States, ${ }^{23}$ the next Supreme Court case involving a statistical disparity between the qualified applicant pool and the employer's workforce, did little to clarify the definition of qualified applicant pool. In Teamsters, the government alleged that an employer had engaged in a pattern and practice of employment discrimination in the hiring and promotion of line truck drivers. ${ }^{24}$ The Court held that a large disparity between the percentage of blacks and Spanish-surnamed Americans employed as line truck drivers and the percentage of these groups within the general population of the area surrounding the defendant's truck terminals was evidence of a pattern or practice of discrimination. ${ }^{25}$ This holding implicitly suggests that the Court thought that any person in the surrounding area was a qualified applicant for the job of a line truck driver. The Court in Teamsters, however, did not specifically point to any characteristics of the line truck driver job that made a labor market comparison to the general population appropriate. Thus, Teamsters provides district courts with no real guidance as to when the general population should be considered the relevant qualified applicant pool.

The Court did attempt to define what it meant by qualified applicant in Hazelwood School District v United States. ${ }^{26}$ In Hazelwood, the government claimed that a school district had engaged in a practice and pattern of discrimination in the hiring of schoolteachers. The dis-

fied applicant pool.

21 Id at 425. The Court, in Wards Cove Packing Co v Atonio, interpreted this burden on the employer as a burden of production rather than as a burden of persuasion. 490 US 642, 659-60 (1989). The 1991 Civil Rights Act overturned that part of the Wards Cove decision and codified the more natural reading of Albemarle. In particular, under the Act, if a plaintiff demonstrates that an employment practice causes a disparate impact, the defendant, to avoid liability, must demonstrate that the challenged practice is job related. Civil Rights Act of 1991, Pub L No 102166,105 Stat 1074, codified at 42 USC $\$ 2000 \mathrm{e}-2(\mathrm{k})(1)$ (A)(i) (1994).

22 Albemarle, 422 US at 425 . Moreover, the 1991 Civil Rights Act has codified this holding. 42 USC \& 2000e-2(k)(1)(A)(ii) (1994).

23431 US 324 (1977).

24 Id at 329.

25 Id at 337 .

26433 US 299 (1977).

27 Id at 301. 
trict court found that plaintiffs' evidence that the school district employed a relatively small number of black teachers lacked probative value because the proportion of black students was also small. ${ }^{28}$ The Supreme Court, in rejecting this evaluation technique, concluded, "a proper comparison was between the racial composition of Hazelwood's teaching staff and the racial composition of the qualified public school teacher population in the relevant labor market." ${ }^{29}$ In a footnote, the Court noted that " $[\mathrm{w}]$ hen special qualifications are required to fill particular jobs, comparisons to the general population (rather than to the smaller group of individuals who possess the necessary qualifications) may have little probative value." ${ }^{30}$ Although the Court in Hazelwood pointed out some relevant factors in determining the relevant labor market, ${ }^{31}$ it did not provide a legal standard for deciding which labor market participants to properly include in the qualified applicant pool. ${ }^{32}$

28 Id at 304 (describing the district court holding that "statistics showing that relatively small numbers of Negroes were employed as teachers" were not probative because "the percentage of Negro pupils in Hazelwood was similarly small").

29 Id at 308 (stating which statistical comparisons are proper in employment discrimination cases). This Comment does not address the degree of statistical disparity between the minority composition of the employer's workforce and the minority composition of the qualified applicant pool necessary for a court to find discrimination. That particular issue is addressed by the EEOC in the following way: If the selection rate for the protected group is less than four-fifths, or 80 percent, of the selection rate for the most favored group, the requirement is presumed to have a disparate impact. 29 CFR $\S 1607.4$ (D) (1999). This standard has been criticized by commentators and rejected by courts. See, for example, Elaine W. Shoben, Comment, Differential Pass-Fail Rates in Employment Testing: Statistical Proof Under Title VII, 91 Harv L Rev 793, 80511 (1978) (criticizing the four-fifths rule for not taking into account sample size differences and comparing only ratios); Clady $v$ County of Los Angeles, 770 F2d 1421, 1428 (9th Cir 1985) (rejecting the four-fifths test and noting that the EEOC guidelines do not have the force of law). See also Joseph L. Gastwirth, Employment Discrimination: A Statistician's Look at Analysis of Disparate Impact Claims, 11 L \& Ineq J 151, 155 (1992) (suggesting a statistical test for determining whether a firm has engaged in discrimination).

30 Hazelwood, 433 US at $308 \mathrm{n} 13$ (noting that in different cases different comparisons will be appropriate based on the job skills required for the employment in question).

31 The Court noted the following factors as possibly relevant to the determination of the qualified applicant pool for teaching positions in the Hazelwood School District: "(i) whether the racially based hiring policies of the St. Louis City School District [a neighboring city school district which had a policy of trying to maintain a 50 percent black teaching staff] were in effect as far back as 1970, the year in which the census figures were taken; (ii) to what extent those policies have changed the racial composition of that district's teaching staff from what it would otherwise have been; (iii) to what extent St. Louis' recruitment policies have diverted to the city, teachers who might otherwise have applied to Hazelwood; (iv) to what extent Negro teachers employed by the city would prefer employment in other districts such as Hazelwood; and (v) what the experience in other school districts in St. Louis County indicates about the validity of excluding the City School District from the relevant labor market." Id at 312.

32 In both Teamsters and Hazelwood, the government brought the suit based upon the theory of a "pattern or practice" of discrimination. In "pattern or practice" cases, the employer's discriminatory intent is relevant to establishing a violation of Title VII. Teamsters, 431 US at 336 (stating that in a pattern or practice case the plaintiff must establish that discrimination is the defendant's "standard operating procedure"). In disparate impact cases, discriminatory intent is not 
After Teamsters and Hazelwood, there was a great deal of uncertainty regarding how to determine the composition of the qualified applicant pool. This uncertainty is exemplified by the Ninth Circuit's ruling in Wards Cove Packing Co v Atonio, ${ }^{33}$ which the Supreme Court subsequently overruled in its next attempt (and failure) to define the scope and shape of the qualified applicant pool. ${ }^{34}$

In Wards Cove, the plaintiffs claimed that an Alaskan cannery's hiring practices had a disparate impact on non-white workers. ${ }^{35}$ As a threshold matter, the plaintiff showed that there were a high percentage of non-white workers in lower paying cannery jobs and a low percentage of such workers in defendant's noncannery positions. ${ }^{36}$ The Court rejected this statistical comparison as irrelevant, reiterating that the "proper comparison [is] between the racial composition of [the atissue jobs] and the racial composition of the qualified ... population in the relevant labor market." Unfortunately, the Court in Wards Cove did not define which labor market participants were part of the qualified applicant pool for the noncannery positions.

In sum, despite a number of different rulings tangentially related to the issue of qualified applicant pool determination, there is no meaningful Supreme Court precedent on exactly how a district court should decide the issue. This lack of precedent leaves a critical gap in the law because the make-up of the qualified applicant pool is an èsential part of a plaintiff's prima facie disparate impact case.

relevant. However, in "pattern or practice" cases, "[w] here gross statistical disparities [between the employer's workforce and the qualified applicant pool] can be shown, they alone may in a proper case constitute prima facie proof of a pattern or practice of discrimination." Hazelwood, 433 US at 307-08 (citations omitted). A statistical disparity between the minority make-up of the employer's workforce and the minority make-up of the qualified applicant pool may also be relevant as proof of discriminatory intent in individual disparate treatment cases. See Furnco Construction Corp v Waters, 438 US 567, 580 (1978) (stating that the district court "was entitled to consider the racial mix of the work force when trying to make the determination as to motivation"). Thus, the qualified applicant pool determination may be relevant in "pattern or practice" and disparate treatment cases, as well as in disparate impact cases.

33827 F2d 439, 444 (9th Cir 1987), revd, 490 US 642 (1989).

34 Wards Cove Packing Co v Atonio, 490 US 642, 650 (1989) (referring to the Ninth Circuit's finding that statistics comparing the percentage of minority workers in low skill positions with the percentage of minority workers in high skill positions were sufficient to support an inference of discrimination). Obviously, such comparative statistics, as the Supreme Court recognized, are inapplicable when defining the "qualified" applicant pool.

35 The alleged illegitimate hiring practices included nepotism, a rehire preference, a lack of objective hiring criteria, separate hiring channels, and a practice of not hiring from within. Id at 650 (stating that the court of appeals had relied on plaintiff's "statistics showing a high percentage of nonwhite workers in the cannery jobs and a low percentage of such workers in the noncannery positions").

36 Id at 650 .

37 Id, citing Hazelwood, 433 US at 308. 


\section{B. Lower Courts' Methodology to Determine the Qualified Applicant Pool}

Because the Supreme Court has not laid out specific guidelines for defining the scope of the qualified applicant pool, district courts have developed various methods for making this determination. In addition, because qualified applicant pool determinations are typically considered findings of fact, a circuit court will usually defer to the judgement of the district courts on this issue.

This Part outlines the two principal methods district courts have used to define the qualified applicant pool and then demonstrates how, in practice, each of these methods inevitably leads to an ad hoc determination of the qualified applicant pool.

\section{The "applicant flow" method.}

One method that courts use to determine the qualified applicant pool is based on the idea of "applicant flow." The applicant flow method considers only those labor market participants who actually apply for the job at issue as the relevant qualified applicant pool. ${ }^{30}$ Using the facts of Wards Cove as an example, a court following the applicant flow method would look only at those applicants who applied for noncannery positions as the qualified applicant pool.

The obvious flaw with the applicant flow method is that it ignores the effect that a hiring requirement that is known to have a disparate impact would have on a potentially qualified applicant's decision whether or not to apply for the job in the first place. It is unlikely that a potentially qualified applicant would take the time to apply for a job if she knew that a particular hiring requirement would prevent her from getting the job. ${ }^{20}$ In addition, the applicant flow method will in-

38 See De Medina $v$ Reinhardt, 686 F2d 997, 1004 (DC Cir 1982) (noting that the definition of the relevant labor market is generally reviewed on appeal under the clearly erroneous standard as an essentially factual matter); Castaneda v Pickard, 648 F2d 989, 1003 (5th Cir 1981) (stating that the determination of the relevant labor market "is an essentially factual matter within the special competence of the district court").

39 See Hazelwood, 433 US at 308 n 13 (finding applicant flow statistics very relevant); United States $v$ County of Fairfax, 629 F2d 932, 940 (4th Cir 1980) (suggesting that applicant flow data is the most salient proof as to the proper labor market); Anderson $v$ Douglas \& Lomason Co, 26 F3d 1277, 1286-87 (5th Cir 1994) (stating that "applicant flow figures are the preferred method by which to measure an employer's hiring practices" by using "applications of those persons who actually sought employment" with the defendant to determine the available labor pool); Hester v Southern Railway Co, 497 F2d 1374, 1379 (5th Cir 1974) (stating that "[t]he most direct route to proof of racial discrimination in hiring is proof of disparity between the percentage of blacks among those applying for a particular position and the percentage of blacks among those hired for the position").

40 It does not make a difference whether the applicant, who is otherwise qualified, does not apply because she knows that she does not meet the hiring requirement, or she knows, in a probabilistic sense, that she is unlikely to meet the requirement due to her protected class. In either 
sulate the most egregious discriminators from suit under a disparate impact theory of discrimination because these discriminators, known for their discriminatory practices, are the least likely to receive applications from minorities.

\section{The proxy labor market approach.}

The other method that district courts typically use to determine the scope and shape of the qualified applicant pool is to look at the minority composition of some proxy labor market. ${ }^{41}$ The proxy labor market is usually some composite of the current holders of the types of jobs at issue. The court then assumes, by analogy, that the composition of this proxy labor market is also the composition of the qualified applicant pool.

For example, in NAACP v Town of East Haven, the plaintiffs claimed that the town's hiring practices had a discriminatory impact on blacks. ${ }^{43}$ The court used all the certified teachers within a particular region as a proxy for the qualified applicant pool of teachers for East Haven public schools. ${ }^{44}$ That is, the court assessed the racial composition of all the certified teachers in the surrounding region and then proceeded in its disparate impact analysis assuming this composition was the same as the composition of the qualified applicant pool.

The proxy labor market approach, while simple, is flawed for three reasons. First, given the historical roots of discrimination, the labor market proxies courts usually choose (for example, current job holders in the types of jobs at issue) will underestimate the number of minorities in the qualified applicant pool. In particular, by assessing the minority composition of the qualified applicant pool by reference to the current holders of the jobs at issue when those current job holders received their employment in an era of systematic discrimina-

case, the applicant flow method will construct a distorted qualified applicant pool. See Barbara Lindemann and Paul Grossman, 2 Employment Discrimination Law 1707 (ABA 3d ed 1996) (stating that sometimes applicant flow data are distorted "when a defendant's reputation for discrimination, recruiting criteria, or recruiting practices produce disproportionately few minority applicants").

41 See NAACP v Town of East Haven, 998 F Supp 176, 186 (D Conn 1998) (holding that the plaintiffs established a prima facie disparate impact case because, "[i]n an area with a sizeable black population, the [town's] failure to hire a black employee cannot be explained as a normal variance"); Kilgo v Bowman Transportation, Inc, 570 F Supp 1509, 1514-15 (N D Ga 1983) (using national labor pool statistics to assess case of regional and local hiring practices for truck drivers).

42998 F Supp 176 (D Conn 1998).

43 Id at 183.

44 Id at 178. Note that this case involved a claim against the city for discrimination in all public sectors of employment; however, this Comment focuses on how the court constructed the qualified applicant pool for the claim of discrimination in the hiring of teachers for the public schools. 
tion, the court will end up with a proxy labor market which is itself a product of discrimination. Such a proxy labor market approach will, in effect, lock-in and legitimize the current minority composition in the jobs at issue.

Second, the proxy labor market approach does not take into account changing labor market opportunities. The current minority composition in the job at issue only reflects the qualified applicant pool if the current job holders and current qualified job applicants faced the same labor market opportunity at the time they chose to apply for a job or engage in job training. This is unlikely to be the case due to the advent of stricter enforcement of discrimination laws. ${ }^{45}$

Third, the labor market proxy approach ignores any potential labor supply substitution effects. In particular, by focusing on current job holders, the labor market proxy method does not account for those labor market participants who could easily switch into the job at issue. In the schoolteacher labor market for example, the participants not accounted for could include recently retired teachers, teachers at private schools, and recent liberal arts graduates (who could quickly get certified). By ignoring this potentially strong labor supply substitution effect, the proxy approach could underestimate (or overestimate) the minority composition of the qualified applicant pool. Whether the labor proxy approach overestimates or underestimates the minority composition of the qualified applicant pool depends on the minority make-up of the possible substitute labor market participants.

In conclusion, both the applicant flow method and the labor market proxy method of determining the relevant qualified applicant pool are potentially flawed from an economic standpoint. Courts need an alternative legal test to determine the scope and shape of the qualified applicant pool. The antitrust principles outlined in Part III of this Comment provide the substantive basis for such an alternative legal test. Before turning to these principles to define the scope and the shape of the qualified applicant pool, however, it is first necessary to show that labor markets are, from an economic theory standpoint, the same as commodity markets.

\section{THE ECONOMIC EQUIVALENCE OF LABOR MARKETS AND COMMODITY MARKETS}

The standard neoclassical economic model assumes that firms seek to maximize profits and consumers seek to maximize their utility

45 This point, of course, assumes that stricter enforcement of discrimination laws has had an impact on the marketplace. That is, without this enforcement there would be the same amount of discrimination against qualified minority candidates today as was historically the case. 
subject to budget constraints. ${ }^{46}$ From these standard assumptions, demand and supply functions are easily derived. ${ }^{47}$ A supply function shows how a firm's production decision (how much of a product to produce) changes when the price of a product changes. $\mathrm{A}$ demand function shows how a consumer's purchasing decisions change when the price of the product changes. ${ }^{4}$ Firms are not only suppliers of products, but also are consumers of labor. Similarly, consumers are not only purchasers of products, but also are suppliers of labor. In a labor market the price at which the consumers sell their labor is the wage and the quantity of the good produced is the hours of work.

In a commodity market, the equilibrium price is determined by the intersection of the supply and demand functions for that particular product (at a price where the quantity supplied of the product equals the quantity demanded by the consumer). ${ }^{50}$ Analogously, in the labor market, the equilibrium wage is determined by the intersection of the supply and demand functions for labor. There is nothing in the standard economic model that makes commodity markets any different than labor markets - that is, the same rational, utility maximizing assumptions underlie the derivation of supply and demand functions in both types of markets.

Moreover, one would expect similar comparative static results in both commodity markets and labor markets. ${ }^{\text {s. }}$ In a commodity market, as the price of a particular product rises the quantity supplied of that product normally increases (as producers increase production to take advantage of higher prices), and the quantity demanded of that product normally decreases (as consumers substitute to alternative products). ${ }^{53}$ In a labor market, as the wage increases, the quantity of labor supplied normally increases (as working more hours becomes more attractive when wages rise), ${ }^{34}$ and the quantity of labor de-

46 See Hal R. Varian, Microeconomic Analysis 23, 94 (W.W. Norton 3d ed 1992) (discussing basic economic assumptions underlying firm and consumer behavior).

47 Id at $40-48,94-110$.

48 Id at 216.

49 Id at 99.

50 Id at 219 (stating that "[a]n equilibrium price is a price where the amount demanded equals the amount supplied").

51 Comparative static results indicate how a consumer's or a producer's choice changes when an exogenous variable changes (for example, how a consumer's demand for a product changes when the price of that product changes). See Hal R. Varian, Intermediate Microeconomics 9 (W.W. Norton 2 d ed 1990) (defining comparative statics and providing an example).

52 Varian, Microeconomic Analysis at 215-17 (cited in note 46).

53 George J. Borjas, Labor Economics 43-46, 101-51 (McGraw-Hill 1996); Varian, Microeconomic Analysis at 46,116-24 (cited in note 46).

54 Of course, this ignores the backward-bending part of the labor supply curve. In the backward-bending part of the curve a rise in the wage actually reduces the amount of labor supplied because labor market participants switch out of work into leisure. See Borjas, Labor Economics at 43 (cited in note 53). 
manded normally decreases (as producers use capital, which is now relatively less expensive, instead of labor). ${ }^{s 5}$

Because the same economic theory of behavior underlies supply and demand activities in both commodity markets and labor markets, analogous legal principles should be used when defining the scope and shape of either market.

\section{ANTITRUST PRINCIPLES IN THE LABOR MARKET CONTEXT}

\section{A. Antitrust Relevant-Market Principles}

To establish a monopolization claim under Section 2 of the Sherman Act, a plaintiff must show "(1) the possession of monopoly power in the relevant market and (2) the willful acquisition or maintenance of that power." ${ }^{, 66}$ Under step one of the monopolization standard, the determination of the relevant commodity market is crucial.

Typically, plaintiffs in Section 2 cases seek to limit the relevant market to as few producers as possible. This will often lead to a finding that the defendant has a high market share because the defendant's sales in the market will be compared to fewer other firms' sales. ${ }^{5}$ Such a finding is valuable to the plaintiff because courts often infer that a large market share coincides with monopoly power.

In contrast, defendants in Section 2 cases seek to include as many different producers as possible in the relevant market because this will often lead to a finding of a small market share. Because a high degree of market power (i.e., monopoly power) is the gravamen of a Section 2 claim, ${ }^{59}$ a defendant that can prove it has a small market share will typically prevail..$^{\circ}$ Therefore, in monopolization cases, like disparate impact cases, the determination of the relevant market (i.e., either the commodity market or the labor market, depending on the type of case) is a critical element of the cause of action.

The Supreme Court has defined the relevant commodity market for Section 2 cases as the intersection of the relevant product market and the relevant geographic market.

55 Varian, Microeconomic Analysis at 70-74 (cited in note 46).

56 United States $v$ Grinnell, 384 US 563, 570-71 (1966).

57 See Phillip E. Areeda, John L. Solow, and Herbert Hovenkamp, 2A Antitrust Law I 532 at 163 (Little, Brown 1995) (stating that market share is the defendant's share of total sales in a "defined relevant market").

58 See United States v Aluminum Co of America, 148 F2d 416, 424 (2d Cir 1945) ("Alcoa") (finding that 90 percent market share constituted monopoly power, but that it was doubtful if 60 percent would be enough and "certainly" 33 percent would not be enough).

59 Grinnell, 384 US at 570-71.

60 Alcoa, $148 \mathrm{~F} 2 \mathrm{~d}$ at 424.

61 Grinnell, 384 US at 571-76 (defining relevant product and relevant geographic markets to make finding of monopoly power under Sherman Act Section 2). See also Smith v Northern Michigan Hospitals, 703 F2d 942, 954 (6th Cir 1983) (stating that in order to succeed on a mo- 


\section{The relevant product market.}

The relevant product market contains those "products that have reasonable interchangeability for the purposes for which they are produced-price, use and qualities considered." ${ }^{, 22}$ In order to determine whether products are reasonably interchangeable, district courts typically look at the ease of substitution from both the demand and the supply sides of the market.

a) Demand-side elasticity. From the demand side, if a price increase for product $A$ induces most buyers to switch to product $B$, then $\mathrm{A}$ and $\mathrm{B}$ are said to be in the same relevant market. ${ }^{64}$ This is equivalent to saying that there is a high cross-price elasticity of demand between the products. ${ }^{65}$

In its 1992 Horizontal Merger Guidelines, ${ }^{66}$ the Justice Department quantified a demand-side elasticity test in the following fashion: If the producer of product $A$ and the producer of product $B$ were to act together as a hypothetical monopolist, could they impose a "small but significant and nontransitory" price increase? If so, then products $A$ and $B$ are considered to be in the same relevant market. ${ }^{6}$

b) Supply-side elasticity.From the supply side of the market, the elasticity test hinges on the ability of producers to alter their production technology to produce a different product. ${ }^{68}$ For example, if producer $A$ can easily switch its production technology to produce product $B$, then producer $B$ would be constrained in its ability to raise the

nopolization claim plaintiffs must establish the relevant product and geographic markets).

62 United States v E.I. du Pont de Nemours \& Co, 351 US 377, 404 (1956).

63 Areeda, Solow, and Hovenkamp, 2A Antitrust Law $\mathbf{9} 561$ at 252 (cited in note 57) (stating that two products are in the same relevant market if substitutability is very high from either the demand side or the supply side).

64 Of course, to avoid engaging in the so-called "cellophane fallacy," the relevant price from which to evaluate the hypothetical price increase should be the competitive market price, not the monopoly price. See Richard A. Posner, Antitrust Law: An Economic Perspective 128 (Chicago 1976) (discussing the appropriate price level from which to evaluate effects of price increases to determine if products are reasonably interchangeable and in the same relevant market).

65 The Supreme Court recognized this cross-price elasticity of demand principle as relevant to product market determinations in E.I. du Pont de Nemours, 351 US at 394. See also Tunis Bros Co v Ford Motor Co, 952 F2d 715, 725-26 (3d Cir 1991) (finding Ford and comparable tractors in same relevant market due to cross-price elasticity of demand); Syufy Enterprises $v$ American Multicinema, Inc, $793 \mathrm{~F} 2 \mathrm{~d} 990,994$ (9th Cir 1986) (stating that the cross-elasticity of demand must be considered in defining the relevant market); Hayden Publishing Co $v$ Cox Broadcasting Corp, 730 F2d 64, 71 (2d Cir 1984) (stating that when defining the product market, one must consider cross-price elasticity of demand). In short, the relevance of the cross-price elasticity of demand to defining the relevant product market is not simply economic theory, but also part of the legal standard adopted by the courts.

66 ABA Antitrust Section, The 1992 Horizontal Merger Guidelines: Commentary and Text (ABA 1992).

67 Id $\$ 1.11$ at 28.

68 Areeda, Solow, and Hovenkamp, 2A Antitrust Law $\$ 561$ at 253 (cited in note 57). 
price of product $\mathrm{B}$. Thus, producer $\mathrm{A}$ and producer $\mathrm{B}$ should be included in the same relevant market.

The Justice Department in its 1992 Horizontal Merger Guidelines recognized this supply-side elasticity principle as critical to relevant commodity market determinations. In particular, the Justice Department stated that, in assessing the relevant commodity market for merger evaluation purposes, it "will identify other firms not currently producing or selling the relevant product in the relevant area as participating in the relevant market if their inclusion would more accurately reflect probable supply responses., ${ }^{70}$

2. The relevant geographic market.

The Supreme Court has defined the relevant geographic market for Section 2 purposes as "the area of effective competition ... in which the seller operates, and to which the purchaser can practicably turn for supplies. ${ }^{31}$ The ability of a firm to sell its products beyond its immediate location determines the geographic scope of the relevant market. ${ }^{2}$ The Supreme Court has stated that the geographic market must be one that both corresponds to the commercial realities of the industry and represents an economically significant trade area. ${ }^{73}$ Courts have looked at a number of factors in order to define the scope of the relevant geographic market. These factors include, but are not limited to, transportation costs, actual sales, and regional price relationships. $^{74}$

69 The Supreme Court recognized this supplier substitution principle as part of the legal standard for defining the relevant product market in United States v Columbia Steel Co, 334 US 495, 510-11 (1948). See also Brown Shoe Co v United States, 370 US 294, 325 n 42 (1962) (stating that "cross-elasticity of production facilities may [] be an important factor in defining the product market").

70 Guidelines $\$ 1.32$ at 33 (cited in note 66 ) (discussing how to include firms in the relevant product market by evaluating supply responses to a potential price increase in the product of the merging companies).

71 Tampa Electric Co v Nashville Coal Co, 365 US 320, 327 (1961).

72 Areeda, Solow, and Hovenkamp, 2A Antitrust Law $\mathbf{} 550$ at 213 (cited in note 57).

73 See United States $v$ Phillipsburg National Bank \& Trust Co, 399 US 350, 359-62 (1970) (taking into account the commercial realities in the banking industry when determining the relevant geographic market); Brown Shoe Co v United States, 370 US 294, 336-37 (1962) (stating that the relevant geographic market must "both correspond to the commercial realities of the industry and be economically significant") (citations omitted).

. 74 In United States v General Dynamics Corp, the Supreme Court recognized the legal significance of transportation costs for the geographic market determination, stating that "a realistic geographic market should be defined in terms of transportation arteries and freight charges that determine the cost of [delivery]." 415 US 486, 491, 510-11 (1974). See also Erie Sand and Gravel Co v FTC, 291 F2d 279, 282 (3d Cir 1961) (finding that high transportation costs effectively limited the area to which a seller making sand for concrete could conceivably sell); American Crystal Sugar Co v Cuban-American Sugar Co, 259 F2d 524, 528-29 (2d Cir 1958) (finding that high transportation costs limited the area in which sugar refineries could sell).

. The Supreme Court and a number of lower courts have looked at actual sales patterns to de- 
The Justice Department's approach to defining the relevant geographic market mirrors its approach to defining the relevant product market. The 1992 Horizontal Merger Guidelines define the relevant geographic market as "a region such that a hypothetical monopolist that was the only present or future producer of the relevant product at locations in that region would profitably impose at least a 'small but significant and nontransitory' increase in price." ${ }^{75}$ Simply put, the relevant geographic market under the Justice Department's standard is the region encompassing the smallest subset of producers of a product who, acting collectively, could implement a price increase.

In sum, a court's determination of the relevant commodity market for monopolization purposes consists of two parts: (1) the relevant product market and (2) the relevant geographic market. Moreover, there is Supreme Court precedent setting forth legal tests for defining these two markets (for example, the "reasonable interchangeability" test for product market analysis," and the "suppliers to whom buyers could practicably turn" test for geographic market analysis" ${ }^{7}$ ). Thus, in theory, district courts in monopolization cases can, by using these simple legal tests, resolve in a systematic way the issue of which producers are and which producers are not part of the relevant commodity market.

Furthermore, these tests, while not always leading to a perfect delineation of the relevant commodity market, seem to work in most cases. $^{78}$ In addition, by focusing on both demand and supply side con-

termine the scope of the geographic market. See United States $v$ Marine Bancorporation, 418 US 602,619 (1974) (affirming district court determination that relevant geographic market for bank merger was metropolitan area in which all of target's bank offices operated); United States $v$ Pabst Brewing Co, 384 US 546, 550-52 (1966) (examining sales throughout the United States, in a three state area, and in the state of Wisconsin to determine the legality of a merger); Houser $v$ Fox Theatres Management Co, 845 F2d 1225, $1230 \mathrm{n} 10$ (3d Cir 1988) (affirming the district court definition of a local geographic market because patrons of first-run films primarily attended local theatres).

Courts have also looked at regional price relationship to see if two products are in the same geographic market. That is, the court looks to see if the prices of two products in two different regions move together over time; if so, they are arguably within the same geographic market. See Rothery Storage \& Van Co v Atlas Van Lines, 792 F2d 210, 219 (DC Cir 1986) (suggesting that absence of evidence that prices moved independently undercuts allegations that the two areas were actually two separate markets).

75 Guidelines $\$ 1.21$ (cited in note 66) (describing general standard to delineate the relevant geographic market).

76 United States v E.I. du Pont de Nemours \& Co, 351 US 377, 404 (1956) (describing "reasonable interchangeability" test for product market analysis).

77 Tampa Electric Co, 365 US at 327 (describing general test to be used when defining the relevant geographic market).

78 See Re/Max International, Inc v Realty One, Inc, 173 F3d 995, 1017-18 (6th Cir 1999) (finding that the relevant geographic market for real estate agents in northeast Ohio consisted of more than one political subdivision); Queen City Pizza, Inc v Domino's Pizza, Inc, 124 F3d 430, 436-39 (3d Cir 1997) (discussing and applying the relevant product market standard to pizza in- 
siderations, the courts have been able to mold the definition of the relevant commodity market in monopolization cases to reflect the underlying economic theory of firm and consumer behavior. Thus, in the antitrust arena, the legal doctrine is supported by economic theory. As noted earlier, the same cannot be said for the current way courts define the relevant qualified applicant pool in disparate impact cases.

\section{B. Application of Antitrust Relevant-Market Principles to Disparate Impact Cases}

To apply relevant-market principles from antitrust law in the labor market context, one must first define the relevant product market for labor (by reference to the cross-price elasticity of the demand for labor and the elasticity of the supply of labor). Then one must go a step further and define the relevant geographic market for labor.

1. Cross-elasticity of demand in the labor market context.

In a commodity market, cross-price elasticity of demand reflects the degree to which consumers shift from product $\mathrm{A}$ to product $\mathrm{B}$ when the price of product $A$ rises. If the typical consumer is apt to switch from $A$ to $B$, then $A$ and $B$ are considered part of the same relevant product market. ${ }^{79}$ In the labor market context, this same legal test can be applied as follows: Suppose there are two workers, A and $B$. If, when worker $A$ raises her wage (i.e., demands a higher starting salary), the typical employer is apt to switch and hire worker $B$, then worker A and worker B should be included in the same qualified applicant pool. The typical employer is apt to switch to worker B because workers $\mathrm{A}$ and $\mathrm{B}$ have similar skills and worker $\mathrm{A}$ demanded a higher wage. In a very real sense the employer considers workers $A$ and B "interchangeable"; thus they should be included in the same relevant labor market.

\section{Supply elasticity in the labor market context.}

In the commodity market, supply elasticity reflects the degree to which other producers can enter a particular market if a producer in that market were to raise its price (i.e., the scope of potential entrants $\left.^{{ }^{80}}\right)$. For example, suppose producer A makes steel rods and producer B makes steel beams. Also, suppose the production technology is such that a producer can easily switch from making rods to making

gredients); United States $v$ Waste Management, Inc, 743 F2d 976, 979-80 (2d Cir 1984) (addressing the proper commodity market definition for waste disposal services in Texas).

79 See text accompanying notes 64-65.

80 See text accompanying notes $68-69$. 
beams. In this case, producer A and producer B would have a high elasticity of supply (due to the ability of $A$ to switch production and produce steel beams if $B$ tried to raise the price of beams), and would therefore be considered in the same relevant commodity market.

In the labor market context, the idea of supply elasticity hinges on the cost of switching jobs. Take again workers A and B. Suppose A is a teacher in a private school and B teaches in a public school. If, when the public school raises the wage for worker $B$, worker $A$ is apt to switch jobs (akin to changing his production technology from beams to rods) and also is apt to be hired by the public school (akin to being able to produce the same type of steel beams as worker B), worker $A$ and worker $B$ have a high elasticity of supply. Hence, worker A and worker B should be considered in the same qualified applicant pool.

\section{The relevant geographic market in the labor market context.}

In the commodity market context, the relevant geographic market consists of the region to which a buyer could reasonably turn for suppliers. ${ }^{81}$ This Comment has previously noted that courts have used transportation costs, actual sales, and regional price relationships to determine the scope of the relevant geographic market in monopolization cases. Each of these factors has an analog in the labor market context.

A court looking at transportation costs in the labor market context would simply look to the cost of relocating to a particular community for a job, or, alternatively, the costs of commuting to work. A court could use the relationship between these costs and the wages paid in the job at issue as one way to determine the area of the relevant geographic market. ${ }^{83}$ For example, in the law firm first-year associate market the wage paid is substantially more than the relocation costs for a law student located anywhere in the United States. Thus, the relevant geographic market for law firm associates would, most likely, be the entire nation. In contrast, in the fast food worker market, the wage paid is small relative to the transportation costs for a labor market participant living outside of the surrounding neighborhood. Thus, in the fast food labor market, the relevant geographic market would, most likely, be the surrounding neighborhood.

81 Tampa Electric Co v Nashville Coal Co, 365 US 320, 327 (1961).

82 See text accompanying notes 71-74.

83 See Herbert Hovenkamp, Federal Antitrust Policy: The Law of Competition and its Practice 113-14 (West 2d ed 1999) (defining the minimum geographic market for antitrust purposes in terms of a ratio similar to the one advocated here). 
A court looking at actual sales in the labor market context would look at where the current holders of the jobs at issue were recruited. If the firm had previously hired or recruited workers from the entire nation, under an actual sales approach to defining the relevant geographic labor market, the entire nation should be considered the relevant geographic labor market. ${ }^{\text {s4 }}$

A court using regional price relationships to determine the relevant geographic labor market would look at the correlation between the wages paid in two different locations for the same job. If these wages moved together over time, this would provide evidence that the two locations should be included in the same geographic labor market. $^{\text {ss }}$

4. The Merger Guidelines relevant-market approach in the labor market context.

The Merger Guidelines provide another way to define the relevant commodity market. Moreover, as previously indicated, the Guidelines' approach is based upon the same economic principles as the approach developed by the case law. Thus, a court could define the qualified applicant pool by using the Guidelines' approach. This is simply an alternative way to think about applying antitrust principles to define the qualified applicant pool. The 1992 Merger Guidelines define the relevant product market as the smallest subset of products for which, if produced by a single firm, that firm could implement a small but significant price increase. ${ }^{86}$ In the labor market context, this approach would define as the qualified applicant pool the smallest subset of workers who, acting collectively, could implement a small but significant wage increase.

Similarly, the 1992 Merger Guidelines define the relevant geographic market as the region encompassing the smallest subset of producers of a product who, if they acted collectively, could implement a small but significant price increase. ${ }^{87}$ In the labor market context, this approach would define the relevant geographic market as the region encompassing the smallest subset of qualified workers (as defined by the product market test above) who, acting collectively, could implement a small but significant wage increase.

84 Note how in the fast food labor market and the first-year associate labor market a court using the actual sales approach to determining the relevant labor market would come out with the same result as a court using the transportation costs approach.

85 Of course, when doing this a court would have to account for general labor market trends. This could easily be done using a simple regression analysis.

86 See text accompanying note 67.

87 See text accompanying note 75 . 
5. Potential problems with applying antitrust principles in the labor market context.

There are several potential problems with applying relevantmarket principles from antitrust law to define the scope and shape of the qualified applicant pool in Title VII cases.

First, the proper delineation of the qualified applicant pool using antitrust relevant-market principles is a tricky and probably expensive process. ${ }^{88}$ Moreover, determining the qualified applicant pool is only necessary insofar as it allows the plaintiff to establish her prima facie disparate impact case. Thus, the argument would go: forcing plaintiffs to bear this cost simply to establish their prima facie case is unfair.

This argument ignores the basic theory that underlies the Griggs disparate impact theory of discrimination. That is, a facially neutral hiring practice can violate Title VII even if there is no evidence of discriminatory intent on the part of the employer. ${ }^{89}$ An argument can be made that before an inference of discrimination is made in the absence of intent, that inference must be supported by evidence of a disparate impact.

In Griggs, what the Court was most concerned about were practices that were "fair in form, but discriminatory in operation." Whether the hiring practice is "discriminatory in operation" depends on whether the hiring practice has a disparate impact on "qualified applicants." The only way to determine this is to accurately construct the qualified applicant pool. If the qualified applicant pool determination is inaccurate, it is possible that a court could find an employer liable for discrimination where there was no evidence of discriminatory intent and no evidence of discriminatory impact generated by a facially neutral hiring requirement. Such a finding of liability extends Title VII too far and seems unjust. Moreover, a persuasive argument could be made that the plaintiff should bear the cost of accurately constructing the qualified applicant pool, since by making a disparate impact claim the plaintiff basically admits she cannot prove discriminatory intent.

The second potential problem with delineating the qualified applicant pool through antitrust relevant-market principles concerns the availability of data. In order to use the method advocated in this Comment, a court needs extensive data on wages and job mobility. Fortunately, there are a number of sources of data on wages and gen-

88 The fact that litigants in antitrust cases often spend a significant amount of resources trying to define the relevant commodity market is evidence of just how tricky and expensive delineating a market can be.

89 See text accompanying notes 14-17.

90 Griggs, 401 US at 431. 
eral market behavior that are readily available. ${ }^{91}$ Thus, there is no reason to think an economist testifying in a disparate impact case would face any greater data difficulties than an economist testifying in a monopolization case would.

\section{A GUIDE TO APPLYING ANTITRUST PRINCIPLES IN DISPARATE IMPACT CASES}

\section{A. The General Model}

When determining the shape and scope of the qualified applicant pool, a court should make three distinct findings of fact-presumably through expert economist testimony-regarding labor market participant behavior. The first two questions go to defining the relevant product market and the third set of questions goes to defining the relevant geographic market. Courts should ask: (1) Is the labor market participant considered by the typical employer interchangeable with the current job holder? (the cross-price elasticity of demand question); (2) Will a small but substantial increase in the wages paid for the job at issue induce other labor market participants to apply for that job? (the supply elasticity question); and (3) What are the relocation costs in relation to the wages paid? ${ }^{93}$ (the relevant geographic market question). Based on the facts garnered from these three questions, a district court could correctly decide the scope and shape of the qualified applicant pool.

\section{B. Application of the General Model: McClain v Lufkin Industries}

In $M c$ Clain v Lufkin Industries, Inc, the plaintiffs filed a class action lawsuit alleging that Lufkin Industries' subjective hiring requirements, though neutral on their face, had a disparate impact on blacks applying for entry level positions. ${ }^{95}$ The court principally relied on sta-

91 See, for example, The Bureau of Labor Statistics website at <http://stats.bls.gov/> (visited Apr 29, 2000) (providing occupational employment statistics including wage estimates by industry); Sandra L. Hofferth, Wei-Jun J. Yeung, and Frank P. Stafford, Panel Study of Income Dynamics, available online at <http://www.isr.umich.edu/src/psid/index.html> (visited Apr 29, 2000) (providing information on over 50,000 individuals emphasizing the dynamic aspects of economic and demographic behavior).

92 This is not to say that economists always have good data in antitrust cases or that courts always make the correct inferences from the data presented in antitrust cases. All that this Comment is claiming is that there is no reason to think economists and courts would be worse at delineating the bounds of a labor market (i.e., the qualified applicant pool) than they are at delineating the bounds of a commodity market. See text accompanying notes 83-85.

93 Alternatively, the court could focus on the correlation of wages among regions or the area from which the employer generally recruits its applicants to determine the area of the geographic labor market.

$94 \quad 187$ FRD 267 (E D Tex 1999).

95 Id at 273. The plaintiffs in this case also alleged a disparate impact claim in promotion 
tistical evidence to find that the plaintiffs had satisfied their prima facie case of discrimination. This statistical evidence showed that the ratio of blacks to whites in the pool of actual applicants was different from the ratio of blacks to whites in the group offered employment. The court concluded that because most applicants were referred to Lufkin via the Texas Workforce Commission, which screened applicants for certain minimum qualifications, a statistical comparison of applicants to the group offered employment was accurate." This is simply the "applicant flow" method of determining the relevant qualified applicant pool (i.e., persons referred by the Commission to the defendant-and only those persons-who then applied for an entry level position at Lufkin were in the qualified applicant pool). If, instead of using this "applicant flow" method for determining the qualified applicant pool, the district court had applied antitrust principles, the court could have developed a more accurate picture of the qualified applicant pool. In particular, it could have determined the relevant geographic and product markets for qualified applicants.

In determining the relevant product market, the district court could have received evidence from an expert economist regarding supply and demand elasticity. For demand elasticity the court should have asked:

1) Would the typical employer view all labor market participants referred by the Texas Workforce Commission as interchangeable for entry-level jobs?

If the answer to question (1) was yes, then all labor market participants referred to Lufkin by the Texas Workforce Commission should have been included in the qualified applicant pool. ${ }^{\text {9 }}$ The court should have then asked:

2) Would the typical employer view as interchangeable those labor market participants who are referred by the Commission and

decisions. Id. For discussion purposes, however, this Comment focuses solely on the disparate impact claim involving entry level employees.

96 Id at 275-77.

97 Id.

98 Id.

99 In order to get evidence on whether all labor market participants referred to Lufkin by the Commission were "interchangeable," the court could take testimony from other employers of entry level employees in the area surrounding Lufkin. In this way, the court could make a determination as to whether all labor market participants referred by the Commission were indeed "interchangeable" for entry level positions or, alternatively, only a smaller subset of those participants (i.e., perhaps only those participants without a criminal record). If the answer to the interchangeability question is no (not all referred labor market participants are "interchangeable"), the court should look at a smaller subset of those participants to determine the qualified applicant pool. 
those labor market participants who are not referred by the Commission?

If the answer to question (2) was yes, then all labor market participants not referred to Lufkin by the Commission, yet still viewed as interchangeable by the typical employer, should have been included in the qualified applicant pool.

Of course, a court should not stop defining the qualified applicant pool after asking the demand elasticity questions. It should also consider supply elasticity. For example, in Lufkin, the court should have asked:

3) If Lufkin were to raise its wage by a small but significant amount, would other labor market participants not included in the answers to questions (1) and (2) apply for a job at Lufkin?

If the answer to (3) was yes, then all of the labor market participants induced into applying should have been included in the qualified applicant pool.

To define the relevant geographic market, the court could look at any of three different factors: (1) the region from which Lufkin recruits; (2) the correlation between the entry level wages paid by Lufkin and the entry level wages paid in the surrounding area $;{ }^{100}$ or (3) the cost of relocation or commuting. If the court decided to define the geographic market using the cost of commuting or relocating, it could have asked the following series of questions:

(4) For a labor market participant from the region surrounding the plant, what is the ratio of the participant's relocation costs (i.e., the costs of commuting to work) to the wages paid by Lufkin?

If this ratio was reasonably small, then all labor market participants satisfying the product market test that also live in the surrounding area should have been included in the relevant geographic market.

(5) For a labor market participant from anywhere in the state of Texas, what is the ratio of the participant's relocation costs (i.e., the costs of moving near Lufkin's plant or the cost of commuting) to the wages paid by Lufkin?

If this ratio was small, then all of the labor market participants living in Texas who satisfy the relevant product market test should have been included in the qualified applicant pool. The court should have continued this line of questioning until it delineated the boundaries of

100 Note that if these two sets of wages are highly correlated, then presumably the surrounding local areas should be included in the relevant geographic market. 
the relevant geographic market. Having received evidence on the relevant product and geographic markets, the court in Lufkin could have then accurately defined the qualified applicant pool.

\section{CONCLUSION}

The Supreme Court has not provided lower courts with sufficient practical guidance on how to define who is and who is not a qualified applicant in Title VII disparate impact cases. This Comment provides a framework for defining the qualified applicant pool that is grounded in antitrust doctrine and economic theory. It requires district courts to make three labor market determinations: (1) Which labor market participants does the typical employer view as interchangeable? (2) Which labor market participants are likely to switch jobs given an increase in the wage of the job at issue? And, (3) What is the ratio of the relocation costs for a labor market participant to the wages paid? Although these findings may not always be easy to make, district courts have managed to answer the same questions when determining the extent of the relevant commodity market in Section 2 Sherman Act cases.

Because labor markets and commodity markets are the same from an economic theory standpoint, they should be treated the same from a legal standpoint. Moreover, because antitrust relevant-market principles force litigants to couch their arguments in terms of the underlying economic structure of the market, applying these same principles in Title VII disparate impact cases should force, by analogy, litigants in those cases to couch arguments with an eye toward the underlying structure of the relevant labor market. Finally, a district court, using relevant market principles from antitrust jurisprudence, can correctly and, to some extent, predictably determine the scope and shape of the qualified applicant pool. 


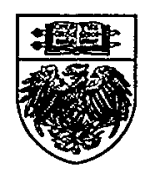

